Slobodan G. MARKOVIĆ

slobamarkovich@gmail.com

\title{
COSMOPOLITAN PROJECTS OF DIMITRIJE MITRINOVIĆ FROM THE 1930s AND THE DILEMMAS OF INTERPRETATION ${ }^{1}$
}

Faculty of Political Science University of Belgrade

\begin{abstract}
Multiple projects of Dimitrije Mitrinović in the 1920s and 1930s never evolved into real political or social movements, although some of them had the capacity for that. It seems that Mitrinović preferred a social club with some mystical elements and loyal followers to the loosely connected members of a political or social movement. The two streams of his actions, which he had originally developed in the 1920s, continued in the 1930s. The first was aimed at social reform and the second at Christian mysticism which was very much based on Gnosticism. The New Britain journal is an example of the first stream, although it also had elements of the second. His correspondence with Eric Gutkind from this period (1927-1932) reveals once more the mystical Mitrinović. His overall efforts are summarized as the project of a Gnostic Christian social club that, at times, developed into a movement. Some dilemmas of interpretation remain since the New Atlantis Foundation, for many decades, kept his archives and correspondence and insisted on its own version of $\mathrm{Mi}$ trinovićs teachings. The first to challenge their views was Predrag Palavestra.
\end{abstract}

Keywords: Dimitrije Mitrinović, The New Britian, Eric Gutkind, social club, Gnosticism, New Atlantis Foundation, Predrag Palavestra

Dimitrije Mitrinović moved to Britian in 1914 and lived there till his deah in 1953. He began his public engagement as a Yugoslav nationalist and remained loyal to this idea until around 1913. Then he became a pan-Christian universalist, deeply rooted in Gnostic and Hermetic ancient and modern traditions (from 1914 until the late 1920s). Finally, he made another step forward during the 1930s.

His name was kept in high esteem after his death by the members of the New Atlantis Foundation, which survived him. Its members mostly left recollections and impressions of Mitrinović focused on his actions aimed at social reforms, on his Christian socialism, on his Eurofederalist ideas, and particularly on his Senate initiative. Most of these activities took place in the 1930s.

1 Some parts of this paper were presented at the round table on Dimitrije Mitrinović organised by Dr. Nemanja Radulović and Dr. Aleksandar Jerkov. The round table was held on December 10, 2013, at the University Library in Belgrade. I would like to thank Prof. Zoran Milutinović of UCL, SSEES, and Prof. Aleksandar Palavestra of the University of Belgrade for their careful reading and comments on this paper. I would also like to express my gratitude to Mr. Martin Levy, Diversity Management and Higher Education Practice Librarian of the JB Priestley Library of the University of Bradford, and Ms. Julie Parry, Archivist of the same library. Their assistance was most helpful. Dr. Nikola Marković of the University Library in Belgrade was very kind to introduce me to the Library's Mitrinović collection. 


\section{Mitrinović's Projects in the 1930s}

The first of these initiatives was launched in 1931 in the form of the Eleventh Hour Flying Clubs. It focused on a future European federation that would gradually evolve into a world federation. More influential than this was The New Europe Group, initiated also in 1931. This group survived until 1957. Mitrinović was successful in convincing Sir Patrick Geddes, a well-known scientist, to become the group's president. He said of the group: "I have been particularly stirred up by your society, the most helpful and exemplary I've come across in London" (Schillan 1972). Among well-known persons who attended meetings of the group were: Henry Wickham Steed, former editor of The Times, Katharine Stewart-Murray, Duchess of Atholl, and the historian George Peabody Gooch (Petrović 2001: 89). Soon a series of lectures was organised and among the group's lecturers were Frederick Soddy, Arthur Kitson, Raymond Postgate and J. V. Delahaye; the secretary of the group became Winifred Gordon Fraser, a lady who remained Mitrinovićs associate until the end of his life (Rigby 2006: 114-116, 197). The aim of the group was the promotion of a European federation. As H. C. Rutherford remarked "it also had the aim of bringing the continent of Europe more actively into the consciousness of the insular British" (Rutherford 1987: 9).

Relative success with lectures led Mirinović to launch a journal that frequently changed its name and survived for two years. Its first title was The New Britain Quarterly (1932-33), then The New Britain Weekly (New Series June 1933 - Autumn 1934). Several short-lived journals also appeared under the titles The New Atlantis: For Western Renaissance \& World Socialism and New Albion (1934). Mitrinovićs plans seem to have been anything but unambitious. D. R. Davies claims that he planned to initiate "seven daily papers circulating throughout Europe in different languages" (Davies 1961: 124).

In The New Britain Mitrinović began again to write "World Affairs" 2 and continued to advocate universal values, to echo his previous mysticism, and to warn against patriotism as the key value. He was in favour of "the relatively very many and yet also relatively very few" persons who would guide the Western Civilisation to a new path which "arrogance and ignorance of the world leaders of today" could not provide. He warned that humanity faced a potential cataclysm. Although many of his statements were rather secular, he preserved some elements of the Gnostic vocabulary as well: "Christ and his Gnosis are the proof and the voucher that Adam, the Species, will not ultimately and truly fail. Anthropos, our kingdom, cannot finally and fatally collapse and lose the thread of its

2 In the period August 1920 to October 1921, Mitrinović wrote "World Affairs" under the pseudonym "Cosmoi" for The New Age. Some of his articles were co-written by the editor of The New Age - A. R. Orage. He again signed "World Affairs" as "M. M. Cosmoi" for The New Britain, and his contributions were published in 10 issues from May 24 to July 26, 1933. 
divine and planetary mission and function" (SWDM 1987: 291-292) ${ }^{3}$. His references to esoteric teachings and his unorthodox formulations caused new problems, and some correspondents openly voiced their dissatisfaction with the style of Cosmoi. The editor C. B. Purdom advised his readers to read Cosmoi's texts four times. The subsequent editor D. R. Davies compared Cosmoi with the English poet Robert Browning, who had to wait to be properly understood. "Mitrinović, too, has to wait. A profounder thinker than Browning, he will probably have to wait longer. No wonder that those earnest readers of New Britain could not understand him, though they read his article forty times" (Davies 1961: 132).

Yet, the sales of New Britain reached 32,000 per week, and by September 1933, 65 groups of New Britain focused on the social state and the "national renaissance" were organised nationwide (Rigby 2006: 126-130). This was the most serious social movement that Mitrinović ever encouraged, although it seems likely that he did not want the movement to grow at such a pace. What happened was that the founders of the movement, including Mitrinović, had no clear vision on how the movement should be structured, and the London group headed by Mitrinović collided with others. As a result, the movement soon disintegrated and, by the end of 1934, essentially disappeared.

This poses certain questions regarding Mitrinović's motives. Was his hesitation to spread the movement only due to his inimical attitude towards political parties, or was there something more at stake? Could a large movement be supervised or at least directed by its intellectual leadership? This may have tormented Mitrinović, and he must have become painfully aware that political movements had to make certain concessions that he was unwilling to make. Its leaders had to simplify their ideas and to accommodate their social aims to suit the needs and conceptions of their average adherents, and apparently not only Mitrinović but also his London colleagues, were unwilling to do this.

His last initiative was the Senate initiative. Since the time of his association with Kandinsky, he was in search of individuals who could lead the world spiritually. Andrew Rigby is of the opinion that Mitrinović took advantage of the London Adler Society and the New Europe Group to find potential recruits for his inner circle and to train such persons for "their practice of cosmopolitan citizenship" (Rigby 1999: 386). What is peculiar is that Mitrinović used an anthroposophist as the basis for his project of social change. He exploited Rudolf Steiner's works to formulate the idea of a threefold state that would have economic, political and cultural spheres, based on equality (economy), fellowship (politics) and liberty (culture). This was one of the main ideas developed within the New Britain Movement and "during the years immediately prior to the Second World War he embarked upon his most sustained educational experiment, seeking to prepare his closest coworkers for living in the new

3 "World Affairs", New Britain (July 5, 1933). 
world which they were trying to create" (Rigby 1999: 387). Yet, there were only 30-40 such coworkers who obviously enjoyed being members of a group headed by Mitrinović, and were proud of the role that the Senate would have if Mitrinovićs utopia ever materialised. Most of them remained loyal to his ideas till the end of their lives. They all had to study the Athanasian Creed, and he himself sometimes used the pseudonym Filioque, a segment from the Athanasian Creed considered heretical in his original Greek Orthodox tradition. "In short, he was trying to create a Kingdom of Heaven. That is, he was attempting the utterly impossible" (Davies 1961: 140).

It is clear that Mitrinović further developed his psychological method, originally individually employed in the years of the Adler Society. Again it had to deal with the ego-ideal and in the simplest terms this notion means "the self's conception of how he wishes to be" (Rycroft 1972: 40). It also refers to the way in which the self wishes to be seen by others. David Davies, the former co-editor of the New Britain Quarterly, a former Congregationalist minister, and a committed socialist in the years of his association with Mitrinović (the 1930s), described the technique that his then spiritual leader used. It is important to note that Davies was a passionate reader and subsequent critic of psychoanalysis and that he himself underwent several psychoanalytic treatments. He testifies that "the circle round Mitrinović contained many psychoanalysts, amateur and professional", and also that Mitrinović himself "was deeply read in Freud and Jung and all the schools" (Davies 1961: 130, 139). In dealing with individuals he implemented the same psychological procedures that Mairet described. Yet, he also had to deal with his followers organised in several smaller groups. These groups consisted of six to seven persons and had three- or four-hour sessions "generally late at night, for one's unconscious was supposed to be less remote in the deep night". A person from the group would then criticise another person from the same group and that person would defend her/himself:

By this time we were fairly launched, and gradually were out in deep waters. A member of the group would then say, in language that lacked nothing of brutality and candour, exactly what he, more frequently she (which made it worse!), thought of me... Frequently those group meetings ended in electric storms. After they closed, we all made our way to a café... We were good friends once more (Davies 1961: 141-142).

Davies confirmed that, with one exception, they "never got anywhere with these meetings" (Davies 1961: 142). There were also larger meetings with twenty to thirty persons present. These "special group meetings" were attended by Mitrinović. In them a person would be singled out for grouping, and then Mitrinović would dictate the line of procedure.

He had a way of penetrating one's last defences, of peeling off, not only one's clothes, but one's skin, and flaying one alive... What Mitrinović said was in- 
frangible truth. The whole twenty or thirty (whatever their number) would take up the theme of Mitrinović's attack, and play variations upon it. The victim was helpless. He was battered (psychically) into stupidity (Davies 1961: 142-143).

The idea behind this exercise was to expose future senators to the most difficult circumstances and prepare them to be individuals in that way, or at least that is what the group members believed. D. R. Davies doubted the effectiveness of this method and considered that Mitrinović "was no nearer creating a community of independent persons after thirty-six years in England, when he died, than he was when he started in 1914" (Davies 1961: 143) ${ }^{4}$. It was already in his Young Bosnian period that Mitrinović began to contemplate how mankind could improve. The technique that he finally employed made his followers face their weaknesses. But did it really make them more prepared to lead a cultural or a social movement? In retrospect one may seriously wonder about that.

There was also a group of prominent British intellectuals gathered around the New Europe Group who were never a part of Mitrinovićs group's psychological exercises but participated in social activities designed by him. In 1948, a delegation of this group attended the Congress of the European Union of Federalists in Rome. The delegation was headed by the radiochemist Frederick Soddy, the nominal president of the New Europe Group, a Nobel Prize winner in 1921 (Palavestra 2003: 299). It is clear that Mitrinović supported Eurofederalist projects. There are, however, some misconceptions about this. For him "Europa" was a cultural and religious concept. Its spirituality was its greatest potential asset, but also a potential for endless clashes between national cultures. He was in search of a pan-European model, and that model, in his worldview, was inseparable from Christian spirituality, although this spirituality was a sort of non-denominational Christianity.

\section{The Reconnection with Gutkind in 1927-1932. Two esoteric poles who failed to create "a union of men round the globe"}

Before he was forced to leave Germany in 1933 as a Jewish intellectual, Eric Gutkind had a liberal circle of eclectic intellectuals who met in Berlin and Potsdam. The circle included Frederick van Eeden, Walter Rathenau, theologian Martin Buber, and occasionally Walter Benjamin and Upton

4 David Richard Davies (1889-1958) was a congregational minister in Wales from 1917 to 1928 , when he resigned due to his new preoccupation with the new socialist social order. He became associated with Mitrinović in London in 1930 and remained his follower until September 1938, when he left him. He became a congregational minister once again at the end of 1940, but found that things had quite changed and joined the Church of England. With the support of the Archbishop of York, William Temple, he was ordained a deacon in Lent, 1941. In his last years he wrote several influential pieces focused on the original sin and was under a strong influence of the American theologian Reinhold Niebuhr and of Martin Luther (Davies 1961). 
Sinclair (LeRoy Finch 1969: 13). Mitrinović briefly belonged to Gutkind's circle just before the Great War and he left a strong impression on him. At a commemorative session held one year after Mitrinovićs death Gutkind said of him: "He was so incomparably present; and often all the others seemed to be less real, to be less present" (LeRoy Finch 1969: 12).

In his writings Mitrinović identified four "bearers of revelation." Of them H. Blavatsky and V. Solovyov died in 1891 and 1900 respectively, when Mitrinović was a child. Rudolf Steiner (1861-1925) was Mitrinovićs contemporary but there are no letters preserved in the archives of NAF that would indicate that there was a written communication between them. Therefore, the only friend of his among the "bearers of revelation" was Gutkind. Although Mitrinović wholeheartedly promoted Gutkind through the pages of The New Age in 1921, they were strangely enough in no communication for many years following the World War. In 1928, Gutkind wrote to him: "If only we had kept up our correspondence just after the war we might have saved years". (UB - SC; NAF, 1.7.1). Mitrinović visited the Gutkinds at Berlin-Gruenan in July 1927. After that visit Eric Gutkind was, in the summer of 1928, very eager to organise a foundation meeting of another association in Germany. He desperately wanted Mitrinović to come to the meeting that was supposed to happen in Hagen near Cologne. In his opinion, without Mitrinović the whole thing would be "spoilt" (UB - SC; NAF, 1.7.1) ${ }^{6}$. After the meeting Gutkind was very enthusiastic.

He wrote to Mitrinović on mutual attraction: "We exist. And this is in itself tremendous source of power. Of course neither you nor I must be only one pole, but poles and I am concentrating on reaching the opposite pole of myself here" (UB - SC; NAF, 1.7.1) ${ }^{7}$. Gutkind was in communication with the Dutch mathematician L. E. J. Brouwer, W. Kandinsky and Alfred Kubin. He envisaged that a group of kindred spirits would gradually enlarge itself. First there would be the two of them (himself and Mitrinović), then "a Three-some", then a group of seven, followed by a group of ten: "Round this kernel of several layers there must be a body of two dozen persons. Then 'The Hundred"'s.

In November 1928, Gutkind admitted to Mitrinović: "I consider your presence most important, as our esoteric discussions form the kernel of the whole idea, which must otherwise remain dead unless we continue our talks"9 (UB - SC; NAF, 1.7.1). He also pointed out that the idea of the

5 E. G. to "My dear and very special Dmitri", 07.11.1928. Members of the New Atlantis Foundation have translated the Gutkid-Mitrinović correspondence from German into English and have typed it in 19 pages. All the quotes from their correspondence in this text are from that translation.

6 Erich Gutkind to "Dear Mensch", Paris, 02.08.1928.

7 Erich Gutkind] to "My Dear Mensch", 18.09.1928. Gutkind has underlined the words himself in this and in all the subsequent letters that have been quoted in this section. 8 Ibid.

9 E. G. to "my dear and very special Dmitri”, 07.11.1928. 
meeting he organised was "to achieve a complete metamorphosis - which is also what you yourself demand" 10 . In organisational terms it seems that Gutkind had no success since Kandinsky did not reply, and others mostly replied negatively, some even campaigned against the idea. ${ }^{11} \mathrm{He}$ expressed hopes that he and Mitrinović could "achieve an act of concentration - maybe I will achieve one pole (the other pole)"12.

In the next letter Gutkind insisted that it was essential for them "to have a talk about esoteric matters", and mentioned that he could summon a conference in Berlin "of so called prominent people" with Brouwer and possibly Henry Borel, and that Mitrinovic could bring two or three persons who understood German (UB - SC; NAF, 1.7.1) ${ }^{13}$. In April 1930, Gutkind wrote about his plans to prepare two books: one that "will go right back into Jewish origins", and "the universal part will be re-written in our spirit." He was very disappointed for not having personal encounters with Mitrinović and he desperately wrote to him: "Our talks were not an isolated once-and-for-all phenomenon - they were of eternity... These talks must live as an eternal source". He warned him that he had unfavourable experience with learned people, psychoanalysts and authors. "These fools and traitors have no intention of helping us", he warned. He insisted that their approach had to be changed: "By an amalgamation of authors we shall not be able to achieve what we saw in our vision" (UB SC; NAF, 1.7.1) ${ }^{14}$.It seems that at some point in late 1930 Mitrinović concluded that Gutkind suffered from the Adlerian inferiority complex and that he tried to avoid responsibility. Gutkind took this very personally and conveyed a message to Mitrinović via Richard Mayer to whom he gave a letter written in February 1931. In that letter he complained that he had no communication with Mitrinović for eight years after the Great War. He put a question in the letter: "How can we create a union of men round the globe, how to build up a new world if impatience motivates our acts?". He begged Mayer to convince Mitrinović to resume collaboration with him, and Mayer passed this letter to Mitrinović (UB - SC; NAF, 1.7.1) ${ }^{15}$.

The split that happened between the two friends was particularly painful to Gutkind. Finally, in a special letter to Mitrinović, sent in February 1931, he insists that the letter contains "the most important thing I have ever been able to communicate to you". He observed that "the inner development" of their "common cause" almost reached the point they

10 Ibid.

11 Ibid. He later informed Mitrinović that "Scheiermann - Adelchen group" also parted from him. Erich Gutkind to "dear Dimitri", Berlin, 11.04.1930.

12 E. G. to "my dear and very special Dmitri", 07.11.1928.

13 E. G. to "dear Dmitri”, Berlin, 05.12 [1928].

14 Erich Gutkind to "my dear Dimitri”, Berlin, 11.04.1930.

15 E. G. to Richard Mayer [before 06.02.1931]. Richard Mayer sent his letter to Mitrinović on February 06, 1931, and in that envelope is enclosed Gutkind's undated letter to Mayer which was therefore written before February 06. 
had "long been hoping for". The vision of Sidereal Birth had to be "free of anything that was either neurotic or escapist in it". He further insists that in his last book Das absolute Kollektiv he separated in himself "the purely Hebraic elements in it wholly and entirely from those that are universalist". He complains that "our dialogue, this magnificent esoteric dialogue, has ceased, has stopped" (UB - SC; NAF, 1.7.1) ${ }^{16}$.

During the course of the Great War Mitrinović definitely abandoned his previous complete identification with the Serbian and Yugoslav cause, and became a universalist instead. He obviously expected something similar from Gutkind and there must have been a point of disagreement between them in terms of local-universalist relation. Their split also came at a moment when Mitrinović began gaining new influence in Britain through various more secular schemes.

More than one year later Gutkind touched upon the character of their mutual link: "the first vision which brought us together... and we do not need to touch on our esoteric unity... was imperfect, a patchwork. It was only part. One part of our truth is buried deep in the past, in the great traditions. But the other part is far beyond us in the future. We are bridge-people...that is our historical relativity in this aeonic moment in which the aeons are separating; at the same time it is our mission and our depth. One bridge-head lies deep in the abyss of time - the other far in the future. (UB - SC; NAF, 1.7.1) ${ }^{17}$.

It is clear that they met again 1932 and they remained in contact until Gutkind emigrated from Germany to the United States in 1933, and later as well. Their collaboration and problems in 1927-1932 only indicated how difficult it was to establish even a small group of three or five like-minded people who could co-operate to create "a union of men round the globe". Obviously, Mitrinović and Gutkind had similar ideas on gathering a global intellectual élite. However, Mitrinović was much more successful with this idea in London than Gutkind had been in Berlin. Their mysticism was mutual and Gutkind repeatedly insisted on their deeply esoteric link. This was something that was close to Mitrinovićs mystical side, but also something that Mitrinović the organiser identified as a potential problem.

Mitrinović wanted to have around him not only intellectuals but also social reformers and generally men of good repute, and to gather all of them he had to offer something more than esoteric teachings. He was able to develop something that Gutkind could not. He simultaneously designed different actions, some of which were seemingly purely secular. Gutkind was confined in any plans he had in Berlin by his book Sidereal Birth. It came to personify him, making him look too esoteric and hence it became very difficult for some of his acquaintances to join him in any organisational form.

16 Erich Gutkind to “dear Dmitri”, Berlin, 14.02.1931.

17 Erich Gutkind to "dear Dmitri”, Berlin, 12.04.1932. 


\section{A Secret Society, a Sect, a Movement or a Social Club?}

Mitrinovićs interest in Christianity and in various mystical and esoteric teachings was his life-long commitment. There is no doubt that for many years he was in search of gnosis - the "true knowledge". This was a quest typical of many of his contemporaries. Coming from a very secular background of Bosnian revolutionaries, his quest signified a radical shift from nationalism to universalism and from local issues to divine depths. Around 1913, once he discovered religious and mystical inclinations within himself, it became his obsession. His interest in psychology fitted quite well with his quest for gnosis. In this he was similar to C. G. Jung. Both of them experienced religious transformation precisely during the Great War, and both were attracted to Gnostic and Hermetic authors. There was something that ancient Gnostics shared with their followers from the $20^{\text {th }}$ century. As Elaine Pagels notes: "For Gnostics, exploring the psyche became implicitly what is for many people today implicitly - a religious quest" (Pagels 1986: 132). Another inspiration came from A. R. Orage, his first conduit to the higher circles of the British public life. Orage considered psychoanalysis as the new form of "the gnosis of man" (Mairet, 1966: xiii).

It is difficult to say how much Mitrinović agreed with the Gnostic concept of the whole visible reality being a product of a false god. In Gnostic teachings the imperfection of reality is a natural consequence of its creator - the false god. Anthropos, unlike the false god, is for the Gnostics the real and good creator, the true father. Mitrinović often referred to Anthropos, but what he meant by this is not easily defined. Since Gnosticism had many incarnations, it is additionally difficult to follow Mitrinovićs reception of this teaching, although he must have been particularly attracted to Valentin's ideas, through Solovyov's influence. One may be also certain that he did not discuss all mystical teachings with all of his adherents and associates.

In one aspect Mitrinović strikingly revised Gnostic ideas. Gnostics generally rejected the visible cosmos, but Mitrinović wished to understand it and to improve it. Since the establishment of the Adler Society in 1927, he advocated certain practical policies that were supposed to make the world better, and this line of action would be fully irrelevant from the Gnostic point of view. Yet, Mitrinović was above all an eclecticist and Gnosticism was only his ideological basis. As it turned out later, it was a good way to fuse mysticism with psychology. His other sources of inspiration were Indian and Chinese religious traditions and philosophy, but that part is beyond the scope of this analysis. It is, however, clear that his main inspiration comes from Judeo-Christian traditions since all of his "prophets" (Steiner, Blavatsky, Nietzsche, Gutkind, Solovyov, Adler and Jung) come precisely from that tradition.

He only partly revealed his religious ideas in his M. M. Cosmoi articles. Therefore, most of his religious points are known from the notes 
collected by his associates and later published by the New Atlantis Foundation. This creates a problem since he seems to have shared his innermost ideas only with a select few. Therefore, one cannot be certain if his religious philosophy can be fully gauged from pamphlets and articles compiled from these notes. It is, however, also clear that starting from his involvement with the Adler Society Mitrinović became fully aware that he was able to recruit secular followers as well.

In the late 1920s and early 1930s he had two types of adherents: 1 ) those interested in mysteries like Stephen Graham, A. R. Orage or Alan Watts, and 2) those interested in his social activism. Naturally there were those who combined both streams. It seems that his last group of 30-40 followers was a combination of the two groups, although overall it was closer to the second one. He also had a group of prominent intellectuals who were associated with him but did not belong to his followers. That group was definitely focused on social activism. Mitrinović was able to gradually get some of his followers interested in mystical religion and philosophy as well. Some of them were interviewed by Andrew Rigby and they all gave statements about the group around Mitrinović in terms primarily based on plans for social reform, the Senate initiative and practical policies.

As is plainly evident from Watts's description, Mitrinović demanded complete loyalty of those whom he initiated in mysteries and even if there were any such persons among the last 40 of his associates, they were unlikely to discuss it publicly. In the 1920s and 1930s, he demonstrated an interest in learning Sanskrit, Tibetan and Chinese and he seems to have learned these languages sufficiently to be able to read sources. That is completely in line with the ideas advocated by Blavatsky and Palmer Hall and was obviously connected with his efforts to understand religious and mystical teachings written in these languages. He also encouraged some of his followers to learn Sanskrit. One of his closest associates was Violet MacDermot. She translated several of Gnostic texts, including Pistis Sofia, a text known to Mitrinović in the interpretation of George Robert Stowe Mead. MacDermot's work attracted many years later the attention of like-minded persons committed to the dissemination of Gnosticism (Schmidt 1978a; Schmidt 1978b; MacDermot 1978) ${ }^{18}$. She seems to have been in charge of collecting Mitrinović's notes on theosophy and Gnosticism, since her notes with such contents have been preserved in the archives of the New Atlantis Foundation (Burgham 2015: 73-74) ${ }^{19}$.

It is not known if Mitrinović belonged to any secret or discreet society in London. He discussed the question of Freemasonry and considered it as one of four major internationals, together with Catholicism, Com-

18 The book by V. MacDermot has a foreword by Stephan A. Hoeller (1931- ), a Gnostic scholar, and a bishop of Ecclesia Gnostica since 1967. I would like to thank Dr. Andrew Rigby for drawing my attention to MacDermot's interest in Gnosticism.

19 I was unable to locate these files in UB - SC, NAF. 
munism, Science and Technology. He considered "the world fraternity of builders" as "the chief factor in the world-guidance as far as this present world is concerned" (SWDM, 266). Many details, however, indicate that he himself might have established some sort of a secret club with universalist aspirations. To his first two followers, Stephen Graham and Fr. Nikolai Velimirovich, he spoke of a secret society composed of the three of them.

In the 1930s, Alan Watts (1915-1973) became Mitrinovićs follower. Later he became an Episcopal minister and then one of the main propagators of Zen and other Eastern philosophies in the United States. He mentions in his autobiography that in 1936 he came to Mitrinovićs apartment at 33, Bloomsbury St. On this occasion Mitrinović invited him "to join an eternal and secret fellowship which will watch you, guard you, and keep track of you wherever you may go in the world". The sign of recognition was carrying a packet of the cheapest brand of cigarettes in England. Mitrinović also said to Watts: "Now if you are inclined to enter into this masonry you must confer with the Jehovah which is in your heart of hearts, and answer me yes or no" (Watts 1972: 123). Alan Watts further mentions that Mitrinović told him about the secret fellowship: "I am going to tell you a mystery which you must never, never reveal to others. It will unlock for you the meaning of all kinds of ancient symbolisms".

Although Watts refers to this in his autobiography as a kind of joke, in another section of his book he mentions that he is not allowed to recount certain conversations since "I promised him not to reveal them" (Watts 1972: 109). Taken together, the two paragraphs written by Watts indicate that Mitrinović conferred upon him secrets that he, even many years later, was not ready to reveal. Instead he offered modified statements that could appear in their full meaning only to those who had already been initiated in them. Watts termed the circle of Mitrinovićs followers "devoted disciples and adoring women", and he described the apartment where Mitrinović lived as "sanctum sanctorum". He also mentions that he both loved and feared Mitrinović "for my Buddhist and Theosophical friends were of the opinion that he was a black magician" (Watts 1972: 109).

Blavatsky acted through Lodge Blavatsky; both theosophists and members of the Golden Dawn had their temples, and everything suggests that Mitrinovićs apartment on Great Russell Street was in fact not merely a meeting point of people who wanted to organise a new and more just social order but also a temple of his teachings. Yet, this does not mean that he established a defined secret society of any kind. He had already experienced utter disappointment when his most loyal adherent A. R. Orage left him in the spring of 1922. So, Mitrinovićs involvement with the Adler Society (1927-1933) was a continuation of his previous efforts to organize a group of persons fully attached to him and his ideas. The Adler Society was a new turning point that transformed his religious ideas into a blend that included both mystical ideas and practical policies. Even his articles written for Orage included more than just Theosophy and Gnosticism. 
They discussed "the changed problem of Britain in Europe" (Mairet 1966: xvii). Since the late 1920s his appreciation of practical policies was obvious. But even his practical policies were still strongly based on teachings of authors who he identified as bearers of revelations: on Eric Gutkind, Rudolf Steiner, Helena Blavatsky and Vladimir Solovyov.

Mairet described Mitrinovićs associates rather differently than they described themselves. He insists that Mitrinović exposed them "to acute emotional experiences, largely analogous to what has been recorded of the conduct of the Gurdhijeff school: they were also collectively employed in a succession of public activities" (Mairet 1966: xxvi). He also discussed the question of successive public activities that Mitrinović launched, which were all brief and usually had chaotic ends. For him "this is the way with most, if not all esoteric schools" (Mairet 1966: xxvi). To understand the spirit of the age one needs to be reminded of the list of intellectuals who, for some time, joined the Gurdjieff school, in spite of his strict methods of dealing with his disciples. The list includes: the American architect Frank Lloyd Wright, A. R. Orage, the French actor Louis Jouvet, and writers Aldous Huxley, Arthur Koestler and Katherine Mansfield (Palavestra 2003: 337). To more secular European readers of the late $20^{\text {th }}$ or early $21^{\text {st }}$ century, mystical clubs and schools may seem very alien. For the spirit of the 1920s, however, it was something novel and promising, and the way that Mitrinović dealt with it places him among very lenient gurus, and among the very rare who appreciated the opinions of his followers and even liked to encourage discussions among them.

His group with esoteric pretensions was fully in line with traditions already present in London. It was a fashionable thing in the Bloomsbury area of London, where Mitrinović lived. Its culture was connected to the Hermetic Order of the Golden Dawn. The Golden Dawn is based on Kabbalah. Adam Kadmon, so often mentioned in Mitrinovićs texts, is the first heavenly man or the idea of the Universe in the Kabbalistic tradition (Palmer Hall 1928). His Gnostic equivalent is Anthropos. Mitrinovićs philosophy is based on the philosophy of Eric Gutkind, as defined in 1910 in his book Sidereal Birth. He came in contact with Gutkind through Kandinsky, who was himself influenced by Theosophy. It may well be that Mitrinović, in addition to many other groups, also had a group of devotees who viewed him as a religious guru in the 1920s and early 1930s. After 1936 any such action was impossible. He suffered a stroke and was very restricted in his activities.

An indication that even the last group of Mitrinovićs followers engaged in certain rituals is provided through a testimony that Predrag $\mathrm{Pa}$ lavestra left describing his meeting with members of the New Atlantis Foundation. Four members of the Foundation met with him on an exact day at an exact time, at $4 \mathrm{pm}$ (instead at $5 \mathrm{pm}$, which would have been the usual tea ritual by the social rules of that period) in the archives of the Foundation based in a cellar, in the last house in which Mitrinović lived, 
in Richmond-upon-Thames. They were seated so as to form a symbolic circle around the table, and in this way they closed the space from all sides of the world. Then they informed Palavestra of the conditions that he was to follow in order to gain access to the materials of the Foundation and they exposed him to "a hermetic test". When Palavestra declined to accept the conditions, his refusal was interpreted as a sign that the hermetic circle did not recognise him as a chosen person to use and make the Foundation's scripts known. This put an end to any co-operation between Predrag Palavestra and the Foundation. He described this experience in his last book, Nekropolje (Necropolis).

When he later described his experience to Mitrinović's brother-inlaw, Stephen Graham, ${ }^{20}$ the latter explained to him: "Well, my dear, you had no chance at all. They closed all exits to you, and you could not have passed anywhere neither to the left nor to the right, nor up nor down. They know such magical tricks and they deal with all kinds of crazy sorceries in order to make themselves look significant. It is for this reason that you had to wait for the four of them to meet on an exact day at an exact place. Had they really wished so you could have peacefully made an agreement with them at any time with an obligatory glass of disgusting cherry" (Palavestra 2012, 34). The very name of New Atlantis was originally used by Francis Bacon for his unfinished utopian novel of the same name (1627). It could imply the building of a perfect society, but it may also be connected to esoteric inspiration, suggesting a transfer of secret teachings from the primal to the new Atlantis. In line with my suggestion that Mitrinović developed two parallel narratives, one must assume that he did not bother some of his more secular followers with the same kind of secret teachings into which he wanted to initiate Watts, and that he obviously did discuss them with Stephen Graham, Father Nikolai Velimirovich, Philip Mairet and most likely some of his later followers as well.

There was something extraordinary about Mitrinović, and both streams of his associates acknowledged that. Mairet was of the opinion that both Mitrinović and Gurdjieff "lived, at least much of their time, at the level of consciousness above our usual human condition; that they were awake to a degree of intensity of which we ordinary people have but rare and brief glimpses, if any" (Mairet 1966: xxii). Rigby summarized the experiences of many of those who had met him: "Time and again people remarked that they sensed that he could see right into, and through, the deepest recesses of their being" (Rigby 2006: 172).

Although his Christianity was focused on personal revelation, nonetheless it was a sort of Christianity. In this sense Z. Milutinović is correct to conclude that "Mitrinovićs Christianity is not a religion in the accepted sense of the term". It is his own doctrine of the Trinity that Milutinović

20 In 1956, three years after Mitrinović's death, Stephen Graham married his sister Vera (Graham 1964: 295-6). 
sees as his theological topography. In it the Father represents the unconscious, the Son the individual and the conscious and the third person, Sophia, represents Wisdom and Universal Humanity (Milutinović 2011: 175).

That Mitrinović's teachings were intimately related to Christianity can be seen from the striking fact that many of his associates and followers were or at some point had been priests/ministers of various Christian churches: Father and later Bishop of the Serbian Orthodox Church Nikolai Velimirovich, Alan Watts, David Davies, Rev. A. D. Belden, Rev. Clifford Harley. They all must have seen a certain Christian essence in his ideas. Mairet, who was well acquainted with Blavatsky's doctrines, described articles by M. M. Cosmoi as "Christian theosophy" (Mairet 1966: 81). Valerie Cooper, in whose studio Mitrinović met Adler, left the recollections of one of her talks with "D.M." about Christ: "Once I said 'But does it really matter whether he really lived on earth or not?' and he replied, "it matters more than anything else in the whole universe" (Rigby 1984: 62, "From the note book of V. V. C.", UB - SC, NAF 1.1.6). This seems to be the statement of a profound Christian believer.

Some of his decisions from the final months of his life indicate what he cared about most deeply at that time. He had lived in a house in Richmond since 1948, and in the last months of his life he was confined to his bed. He asked that several symbolic objects should be placed in his room. They included a copy of Lao Tse, a book of Serbian folk tales and a Christian cross. His gravestone at Highgate cemetery in London includes a special symbol, a spherical cross. "The society 'New Atlantis' used it as a symbol of general unification of mankind and of all world churches and faiths" (Palavestra 2012: 40). Undoubtedly, that is exactly what Mitrinović stood for. Yet, there is no doubt that for him the basis of such a unification of mankind was a kind of Christianity. His Christianity was Gnostic, it contained theosophical components and was strongly under the influence of the Sofian Christianity of Solovyov. His ideas stemmed from various sources. In N. Radulović's opinion, they derived "mainly from theosophic macrohistory... but he was more inclined towards the anthroposophic-Christian version" (Radulović, 2017: 88). At the same time, it was primarily a mystical and Gnostic Christianity focused on introspection and open to various other faiths, and particularly to Indian and Chinese teachings.

Mitrinovićs Gnosticism is a modern version of this teaching, and it fits within the definition of what Gilles Quispel regards as "modern gnosis". Quispel lists within this stream of thought the following persons: Jakob Boehme, William Blake, J. W. Goethe, German historian Gottfried Arnold, and a prominent Hegelian, Ferdinand Christian Baur. Under the same section he mentions Henri-Charles Puech, Károly Kerényi, Carl Gustav Jung and himself as persons who understood Gnostic symbols as "a mythical expression (i.e. projection) of self-experience". One should add also Solovyov and Stephan Hoeller, and in some respects Elaine Pa- 
gels, to this list (Quispel, 1993: 573-574). Mitrinović also belongs to this group of the proponents of "modern gnosis". Two main features of his teachings bring him to this group: his focus on an introspective approach to revelation, and his Sophian Christianity.

Based on all of this I believe that Mitrinovićs efforts could be summarised as a project of a Gnostic Christian social club that, at times, developed into a movement, but was soon reduced, by Mitrinović's own initiatives, back to the format of a club. The aim of the club had been to educate spiritual élites in Britain that could help a utopian transformation of the world. The project had been much more utopian than his associates were later ready to acknowledge. With the magnetic personality of DM around them, even fully utopian endeavours seemed as something worthy of engaging in. Without him they remained merely unfulfilled prophecies.

\section{Dilemmas of Interpretation}

Some of the leading experts on Mitrinović have been under the strong influence of their talks with the members of the New Atlantis Foundation, NAF. The members systematised some of his ideas that had been substantially more chaotic, but they all contained much more mysticism in the original form pronounced by Mitrinović. Andrew Rigby specifically thanked five associates of the Foundation for their help in drafting the first comprehensive analysis of his work and life in English (Rigby 1984) ${ }^{21}$. Members of the Foundation remained fully committed to Mitrinović's ideas as they understood them. They made a kind of commune, bought Mitrinovićs house in Richmond and placed the archives of the Foundation there. When Predrag Palavestra visited them in 1966, seven or eight of them lived in the house. He was allowed to sleep in Mitrinović's room and to consult his archives and his library. Palavestra described the members of the New Atlantis Foundation in sympathetic terms, yet he left a testimony that they claimed to be the sole interpreters of the legacy of their founder. When he asked to take some documents to Belgrade and to copy some other documents for the preparation of Mitrinović's collected works, he was asked to accept certain conditions. "I could not publish a single of Mitrinović's manuscripts without their previous permission. All copyrights for texts written in English belong to them. I am obliged to show the final version of my study before printing it and to accept all their remarks if they refer to my interpretations of some of Mitrinovićs views - since they are the only ones who are called and authorised to advocate them, explain them and pass them to others" (Palavestra 2012, 33).

In 1977, Palavestra published the first edition of his book on Mitrinović, entitled Dogma i utopija Dimitrija Mitrinovića [The Dogma and

21 See "Acknowledgements" in Andrew Rigby, Initiation and Initiative. 
Utopia of Dimitrije Mitrinović], which is still the best study on Mitrinović. The second, expanded edition of this book was published in 2003. The NAF reacted with its own criticism of the last chapter of Palavestra's book on 72 typed pages. To do this they had to translate parts of Palavestra's book for internal use and that task was performed by David Shillan, one of the Trustees of the NAF (Burgham 2015: 259). His translation was revised by Dr. E. D. Goy of the University of Cambridge. This text was written for NAF followers. The text was typed in 1977, and in June 1980 David Shillan personally brought a copy of this text to the University Library in Belgrade. In his last will Mitrinović bequeathed a substantial part of his personal collection of books to this Library (some 2,000 books) and the NAF obviously wanted to make their criticism available to any subsequent researcher of Mitrinović's ideas. In the foreword, the Trustees insist that Palavestra never met Mitrinović "and the Trustees knew him well and worked with him during the last twenty years of his life" (Critique 1980: 1) $)^{22}$. It is characteristic that the Trustees disagreed with the last chapter since it dealt with the period of their founder's life, when he lived with them. However, they also objected to the chapter entitled "Utopian Messianism". The Trustees made no acknowledgment of the great efforts Palavestra made. They rather focused on the points of interpretation in which their views differed from Palavestra's. The fact that in the communist Yugoslavia Mitrinović was half-proscribed, and that prior to Palavestra's book no serious study on him had ever been published in Yugoslavia, while occasional references to him had very negative connotations, was not duly mentioned. They also neglected the fact that Palavestra risked his academic career by discussing the religious aspects of Mitrinovićs thought.

This hypercritical assessment of a very substantial effort that Predrag Palavestra made is quoted here only to illustrate that the Trustees believed themselves to be the only legitimate interpreters of Mitrinovićs ideas and teachings. And they indeed partly succeeded through their publications and personal communications in presenting Mitrinović in the way they understood him. Since some of Mitrinovićs teachings are known only from the NAF pamphlets and from the notes collected by NAF members, one may wonder if they fully represent his ideas? The commitment of the members of the Foundation to their founder even after his death is moving. On the other hand, it seems that they were not always able to process all of Mitrinovićs ideas, and Stephen Graham is only one of several persons who has pointed this out (Palavestra 2003: 323).

In a pamphlet entitled Principles and Aims: New Altantis Foundation, a kind of official interpretation of Mitrinović's ideas has been provided (Principles 1981). It essentially insists on two aspects of his theory. The first is that he rejected "either-or" reasoning and with it he dismissed three traditional laws of thought postulated by Plato and Aristotle. In-

22 A copy of Critique is kept in the Rare Books Department of the University Library "Svetozar Marković" in Belgrade. UL SM - RBD, folder Mitrinović. 
stead he offered the "third force", based on "above, between and beyond the extremes and opposites". The other is that the pattern of trinity has an organic equivalent in the human body, and the succession of three revelations corresponds to three major world views. The first is the cosmic, the second is the individualistic and the third is the universal, based on the "inter-relationship between many individuals". The pamphlet adds that there is also a fourth approach: "to accept the equi-validity of all three revelations simultaneously" (Principles 1981: 12, 20-24). In this last statement the New Atlantis Foundation probably described what it viewed as Mitrinović's ultimate legacy.

Palavestra states that Mitrinović lived in England "like some guru, in a small brotherhood of associates and friends" (Palavestra, 2012: 30). What was the aim of that small brotherhood? Did they ever learn what their founder had in mind when he gathered them? Mitrinović follows Gnostics and certain other mystics in their idea that there is a hidden knowledge within us that we can reach, and he obviously considered himself as a man who should pass on gnosis to others, more specifically to his followers. Moreover, in Mitrinović's and Gutkind's ideas the revelation of their age was the final aim of mankind. What was left was to find and educate a group of humans who would be able to decipher it to mankind. He realised by the late 1920s that there was not a single code of decipherment, but that it needed to be realised through parallel narratives. As early as the age of 49 , due to his illness, he became unable to fuse the two narratives both in terms of theoretical synthesis and in terms of transforming his followers into something more than a social club.

More than half a century after his death his ideas may be only partly identified. His entire teaching was, in my opinion, based on Gnostic and Hermetic foundations filtered by Gutkind and Solovyov. This is, however, only half of the answer to his puzzle. His Young Bosnian nationalism was extinguished in 1913-1914. However, his Young Bosnian revolutionary zeal remained. His reading of mystical texts was always a kind of reading undertaken by a person who never abandoned the enthusiasm of a young revolutionary. His chiliasm and utopianism is, therefore, a blend of mysticism and revolution, a blend that existed among early Christians and many subsequent Christian revivalist movements, but also among some of his contemporaries like A. R. Orage. The Great War made many in Britain lose faith in the prospects of humanity. In this atmosphere of resignation, many a man became open to any new possibility of reconstructing humanity. In Britain of the 1920s one could be a Platonist, a theosophist, a Gnostic and a Socialist, all at once. What was true for Britain was even more so for London. Mitrinović probably chose the most receptive geographic location in the world of that time for spreading his all-human Christian syncretism and for his pan-human socialism. Only in Britain of that time, with so many Christian denominations in crisis, could he have found so many devoted lifelong followers. 


\section{SOURCES}

UB - SC, NAF, University of Bradford, Special Collections, New Atlantis Foundation

UL SM - RBD (University Library "Svetozar Marković" in Belgrade, Rare Books Department), folder Mitrinović

\section{LITERATURE}

Burgham, Emma. The New Atlantis Foundation Dimitrije Mitrinović Archive: Catalogue. University of Bradford, 2015.

"Critique of the last chapter of Dr. Predrag Palavestra's book Dogma i utopija Dimitrija Mitrinovića by the Trustees of the New Antlantis Foundation" [typed text], The New Atlantis Foundation, 1980.

Davies, D. R. In Search of Myself, London: Geoffrey Bles, 1961.

Dedijer, Vladimir. The Road to Sarajevo, MacGibbon and Kee, 1967.

Graham, Stephen. Part of the Wonderful Scene. An Autobiography, Collins, 1964.

Gutkind, Eric. The Body of God. First Steps Toward an Anti-Theology. The Collected Papers of Eric Gutkind. Horizon Press, 1969.

LeRoy Finch, Henry. "Introduction", in Eric Gutkind, The Body of God. First Steps Toward an Anti-Theology. The Collected Papers of Eric Gutkind. Horizon Press, 1969, pp. 7-20.

Macdermot, Violet. The fall of Sophia: A Gnostic text on the redemption of universal consciousness, Lindisfarne Books, 2001.

Mairet, Philip. A. R. Orage. A Memoir, University Books, 1966 [1 $1^{\text {st }}$ ed. 1936].

Mairet, Philip. "Reintroduction", in Idem, A. R. Orage. A Memoir, University Books, 1966, pp. v-xxx.

Milutinović, Zoran. Getting over Europe. The Construction of Europe in Serbian Culture, Rodopi, 2011.

Pagels, Elaine. The Gnostic Gospels, Penguin, 1986.

Palavestra, Predrag/Палавестра, Предраг. Доіма и уйойија Димитирија Митириновића [Dogma and Utopia of Dimitrije Mitrinović]. Zavod za udžbenike, $2^{\text {nd }}$ enl. ed., 2003 [1 $1^{\text {st }}$ ed. 1977].

Palavestra, Predrag/Палавестра, Предраг. Некройоље [Necropolis], book 1, Dosije and Zavod za udžbenike, 2012.

Palmer Hall, Manly. The Secret Teachings of All Ages. An Encyclopaedic Outline of Masonic, Hermetic, Qabbalistic and Rosicrucian Symbolical Philosophy, San Francisco, 1928.

Petrović, Nenad V./Петровић, Ненад В. „Димитрије Митриновић”, in Idem, Оїлеgи о смислу и заблуgама [Idem, "Dimitrije Mitrinović", in Essays on Sense and Minconceptions], Association of Writers of Serbia, 2001, pp. 73-106.

Principles and Aims. New Atlantis Foundation, The New Atlantis Foundation, 1981. 
Radulović, Nemanja. "The Sexual-Mystical Sophianism of Dimitrije Mitrinović", La Rosa di Paracelso, No. 1 (2017), pp. 87-99.

Rigby, Andrew. Initiation and Initiative. An Exploration of the Life and Ideas of Dimitrije Mitrinović, East European Monographs, 1984.

Rigby, Andrew. "Training for Cosmopolitan Citizenship in the 1930s: The Project of Dimitrije Mitrinovic", Peace and Change, vol. 24, no. 3, July 1999, pp. 379-399.

Rigby, Andrew. Dimitrije Mitrinović. A Biography, William Sessions Ltd., 2006.

Rutherford, H. C. "Erich Gutkind as Prophet of the New Age", The New Atlantis Foundation, 1975.

Rutherford, H. C. "General Introduction", in Idem (ed.), Certainly, Future. Selected writings of Dimitrije Mitrinović, Boulder, 1987, pp. 1-16.

Rycroft, Charles. Dictionary of Psychoanalysis, Penguin Books, 1972.

Schmidt, Carl. Pistis Sophia, tr. and notes by Violet Macdermot, Nag Hammadi Studies, Vol. 9, E J Brill, 1978a.

Schmidt (ed.), Carl. The books of the Jeu and the untitled text in the Bruce codex, tr. and notes by Violet Macdemot, Nag Hammadi Studies, Vol. 13; The Coptic Gnostic library, Brill, 1978b.

Shillan, David. "Biotechnics: the practice of synthesis in the work of Patrick Geddes", sixteenth foundation lecture, The New Atlantis Foundation, 1972.

Watts, Alan. In My Own Way. An autobiography 1915-1965, Pantheon Books, 1972.

\section{ABBREVIATIONS}

SWDM - Mitrinović, Dimitrije. Certainly Future, Selected writings of Dimitrije Mitrinović, H. C. Rutherford (ed.), Boulder, 1987.

SDDM - Mitrinović Dimitrije/Мийриновић, Димийрије, Сабрана gјела [Collected Works of Dimitrije Mitrinović, P. Palavestra (ed.)], Svjetlost, 1991, in three volumes. 
Слободан Г. Марковић

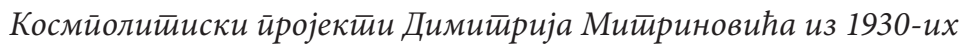

и дилеме ичумачень

Резиме

Узастопни пројекти Димитрија Митриновића из 1920-их и 1930-их никада нису еволуирали у стварне политичке или друштвене покрете, мада су неки од њих имали потенцијал за нешто такво. Изгледа да је Митриновић више волео неку врсту друштвеног клуба, с извесним мистичким елементима и оданим следбеницима, у односу на слабо повезане чланове политичког или друштвеног покрета. Два правца његовог деловања, које је првобитно развио током 1920-их, наставила су се и током 1930-их. Циљ првог била је реформа друштва, а другог хришћански мистицизам који је у многоме био заснован

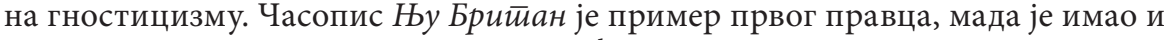
елементе другог. Преписка Митриновића с Ериком Гуткиндом из овог периода (1927-1932) још једном открива мистичког Митриновића. Његови укупни напори резимирани су у пројекту гностичког хришћанског клуба који се повремено развијао до нивоа покрета. Поједине дилеме у погледу тумачења остају и даље нерешене јер је Фондација Нова Атлантида, током више десетлећа, чувала његову архиву и преписку и истрајавала на сопственој верзији Митриновићевог учења. Први који је довео у питање њихове погледе био је Предраг Палавестра.

Кључне речи: Димитрије Митриновић, Њу Британ, Ерик Гуткинд, друштвени клуб, гностицизам, Фондација Нова Атлантида, Предраг Палавестра

Примљено: 15. 10. 2018.

Прихваћено: 20. 12. 2019. 